\title{
Estimation of Plasma D-Dimer Levels in Sudanese Women with Preeclampsia
}

\author{
Sara Mohamed Nagib Abdelgadir, Nasr Eldeen Ali Mohammed Gaufri* \\ Department of Haematology, Faculty of Medical Laboratory Sciences, Alneelain University, Khartoum, Sudan \\ Email: *Nasralimohammed@yahoo.com
}

How to cite this paper: Abdelgadir, S.M.N. and Gaufri, N.E.A.M. (2017) Estimation of Plasma D-Dimer Levels in Sudanese Women with Preeclampsia. Open Access Library Journal, 4: e3210.

http://dx.doi.org/10.4236/oalib.1103210

Received: December 6, 2016

Accepted: January 16, 2017

Published: January 19, 2017

Copyright $\odot 2017$ by authors and Open Access Library Inc.

This work is licensed under the Creative Commons Attribution International License (CC BY 4.0).

http://creativecommons.org/licenses/by/4.0/ (c) (i) Open Access

\begin{abstract}
Background: The literature suggests that the haemostatic abnormalities have taken a big part in preeclampsia. D-dimer is a biomarker of fibrin formation and degradation. Objective: The present study was aimed to estimate and evaluation of the plasma D-dimer levels in Sudanese preeclampsia women. Material and Methods: This is an analytical descriptive case control study done during March 2016. A total of 100 participants were enrolled in this study, classified into two groups: the first group consisted of 50 Sudanese women diagnosed by preeclampsia as patients group, while the second group consisted of 50 normotensive women and their age matched to patients, designated as normal control group. 3 milliter of veins blood samples were collected in containers containing $3.2 \%$ tri sodium citrate as anticoagulant, then the platelet-poor plasma was prepared immediately by centrifuging for 15 minutes at approx $3000 \mathrm{rpm}$. The plasma D-dimer levels were done using MISPA-i2 (Switzerland). The data were analyzed by using SPSS (version 20). Results: The current study showed that the D-dimer level was statistically significant higher in preeclampsia women compared with normotensive pregnant women (Mean \pm SD: $1.016 \pm 0.158$ vs $0.168 \pm 0.045$ with $P$ value 0.000 , respectively). Conclusion: This study concluded that the plasma $\mathrm{D}$-dimer level was significantly elevated in Sudanese women with preeclampsia.
\end{abstract}

\section{Subject Areas}

Hematology

\section{Keywords}

D-Dimer, Hypercoagulable, Preeclampsia, Sudan

\section{Introduction}

Preeclampsia (PE) or Eclampsia (E) is one of the most common complications 
characterized by hypertension (raised blood pressure) [1]. The development of hemolysis $(\mathrm{H})$, elevated liver enzyme (EL), low platelets (LP) is called HELLP syndrome [2] [3]. During normal pregnancy, the placenta vascularizes to allow for the exchange blood [4], water, gases, solute, including nutrient and wastes between the mother and fetal circulation [5]. The poor placental perfusion was occurred in abnormal pregnancy, which can affect of some [6] maternal organs, such as dysfunctional liver (rupture affected by coagulation factor), renal failure [7] or UTI during gestation [8], stroke and one of the signs is the excretion of large amount of protein in the urine appearing after the 20 or 23 weeks of gestation [1]-[5]. Preeclampsia women present with headache, blurred vision, flashing lights, abnormal pain especially in the upper right side, nausea, shortness of breath. Many factors obviously increased the preeclampsia in pregnant women [9] [10], for instance: history Diabetes mellitus, history of hypertension, lupus anticoagulant, rheumatoid arthritis, advanced maternal age more than 35 years, multiple gestation [9], chronic hypertension [11], Thrombotic Thrombocytopenic purpura [12], and history of preeclampsia [13]. The pregnancy is associated to physiological changes for the maintenance of the fetoplacental unit [14]. The haemostatic abnormalities in preeclampsia is hypercoagulable state, this is due to activation of coagulation and increased fibrinolysis, which may elevate the plasma D-dimer [14]. The preeclampsia diseases are also characterized by seizures as a sign of affection of the cerebral vessels (neurologic), or disseminated intravascular coagulation, but pulmonary edema is rare [5].

\section{Material and Method}

This is a descriptive case control study done at Bahri Teaching Hospital and Al neelain University faculty of medical laboratory science, Khartoum, Sudan. A total of 100 pregnant women were enrolled in this study, 50 were known Sudanese women professionally diagnosed by preeclampsia (high blood pressure and proteinuria before 34 weeks of gestation) their mean age is $28.1 \pm 2$ years $\{17$ (34\%) in first gestational and $33(66 \%)$ in second gestational\} admitted to Obstetrics and Gynecology department at Bahri Teaching Hospital, Khartoum, Sudan during March 2016. Other 50 were normotensive women designated as normal healthy control group matched with patients in nationality, age and gestationalage. $3 \mathrm{ml}$ of venous blood were collected in a container contains 3.2\% trisodium citrate at a ratio of 9:1 as anticoagulant, then platelets poor plasma (PPP) was immediately prepared by centrifuged for 15 minutes at $3000 \mathrm{rpm}$ at room temperature. The plasma D-dimer levels were measured using (MISPA-i2 Reagent-Switzerland). This study was approved by the faculty of medical laboratory sciences Alneelain University ethical committee, the informed consent was taken from every woman enrolled in this study before the sample was collected. A woman has a history of coagulopathy, liver disease or any inflammatory disorders were excluded from this study. The data was analyzed by using Statistical Package for the Social Sciences (SPSS) version 20. The T. test was used to compare the plasma D-dimer level between the two study arms, and the level of $p$ 
valueless than 0.05 considered significance.

\section{Result}

A total of 100 women were enrolled in this study, 50 of them known Sudanese female diagnosed with preeclampsia wear attended to Bahri Teaching Hospital as test group and others 50 of normotensive pregnant women matched with patient in age and in gestational age as control group.

The current study showed that the D-dimer levels was statistically significant higher in Sudanese woman with preeclampsia in compares on with those normotensive pregnant women Mean \pm SD $(1.016 \pm 0.158$ vs $0.168 \pm 0.045$ with $\mathrm{P}$ value 0.000$)$ (Table 1$)$.

\section{Discussion}

The hypercoagulability in pregnancy, this can in turn lead to complication like early onset hypertensive disorder of pregnancy [2] [15], that lead to decrease in natural anticoagulant and activation and increase in coagulation in early stage of fibrin clot formation, activated thrombin cleaves fibrinogen, soluble plasma protein convert immediately fibrin clot lead to micro vascular thrombi [15] [16]. The criteria that define pre-eclampsia have not changed over the past decade [17] [18]. Pre-eclamsia is a multisystem disorder that complicates $3 \%-8 \%$ of pregnancies in western countries and constitutes a major source of morbidity and mortality worldwide [19] [20]. While in Sudan the complication with pre-eclampsia/eclampsia is $4.2 \%$ [21]. The current study aimed to estimate and evaluation of the plasma D-dimer level in Sudanese preeclampsia women. The analysis of the present study revealed that the D-dimer level was statistically significant elevated in the woman with preeclampsia in compares on with those normotensive pregnant women (Mean \pm SD1.016 \pm 0.158 vs $0.168 \pm 0.045$ with $P$ value 0.000 ) respectively. This finding was in concordance with eight previous studies, the first study done in 2012 by Pinheiro Mde B. et al. in meta-analysis who was indicates that increased plasma D-dimer is associated with preeclampsia vs normotensive pregnant subjects [22]. Second study by Bozkurt $\mathrm{M}$ et al. (2015) whore ported that D-dimer level was increased in preeclampsia and eclampsia patients [23]. Third study showed that the plasma D-Dimer concentration level were significant higher in patient with preeclampsia women compression with normotensive pregnant women (Means $1.016 \pm 0.158$ ) versus (Mean \pm SD $0.168 \pm 0.045$ with $\mathrm{p}$ value $<0.000$ ) respectively [24]. Fourth and fifth studies done in Japan (1991) and Norway (1997) by Terao et al. and Schjetlein et al. respectively, who concluded that the D-Dimer level was increased in preeclampsia and eclampsia patients [25] [26]. Six, Seven and Eight studies were cited by Bellart et al. in Spain (1998) He et al. in Sweden (1997) and Heilmann et al. in Germany (2007) who reported that the D-dimer levels were significant higher in patient with preeclampsia compared with normotensive pregnant women [27] [28] [29]. The interesting finding of this study was in contrast with Dusse et al. (2003) in Brazil [30], and with study done in Portugal (2008) by Catarino et al. 
Table 1. Association of plasma D-dimer levels in preeclampsia woman and normotensive pregnant.

\begin{tabular}{ccccc}
\hline Parameter & Subject & Number & Mean \pm SD & p value \\
\hline \multirow{2}{*}{ D-dimer Ng/mg } & Patient & 50 & $1.016 \pm 0.158$ & 0.000 \\
& Control & 50 & $0.168 \pm 0.045$ & \\
\hline
\end{tabular}

T-test was used for comparison. p value $<0.05$ was considered significant.

[31] who showed that there is no any significant different in D-dimer level between preeclampsia woman and normotensive woman this might be due to small samples size in our study our may attributed to different ethnic background of population.

\section{Conclusion}

This study concluded that the hypercoagulable state was present in Sudanese women with preeclampsia.

\section{References}

[1] (2000) Report of the National High Blood Pressure Education Program Working Group on High Blood Pressure in Pregnancy. American Journal of Obstetrics \& Gynecology, 183, s1-s22. https://doi.org/10.1067/mob.2000.107928

[2] Martin Jr., J.N., Rinehart, B.K., May, W.L., Magann, E.F., Terrone, D.A. and Blake, P.G. (1999) Thesepctrum of Sever Preeclampsia: Comparative Analysis by HELLP (Hemolysis, Elevated Liver Enzyme Levels, and Low Platelet Count) Syndrome Classification. American Journal of Obstetrics \& Gynecology, 180, 1373-1384. https://doi.org/10.1016/S0002-9378(99)70022-0

[3] Drakeley, A.J., Le Roux, P.A., Anthony, J. and Penny, J. (2002) Acute Renal Failure Complicating Severe Preeclampsia Requiring Admission to an Obstetric Intensive Care Unit. American Journal of Obstetrics \& Gynecology, 186, 253-256. https://doi.org/10.1067/mob.2002.120279

[4] Mustafa, R., Ahmed, S., Gupta, A. and Venuto, R. (2012) Comprehensive Review of Hyper Tension in Pregnancy. Journal of Pregnancy, 2012, 1-19.

[5] (2002) Diagnosis and Management of Preeclampsia and Eclampsia. International Journal of Gynecology \& Obstetrics, 77, 67-75.

https://doi.org/10.1016/S0020-7292(02)80002-9

[6] Duss, L.M., Rios, D.R., Pinheiro, M.B., Cooper, A.J. and Lwaleed, B.A. (2011) PreEclampsia: Relationship between Coagulation, Fibrinolysis and Inflammation. Clinica Chimica Acta, 4129, 17-21. https://doi.org/10.1016/j.cca.2010.09.030

[7] Maynard, S.E., Karumanchi, S.A. and Thadhani, R. (2008) Hypertension and Kidney Disease in Pregnancy. In: Brenner, B.M. and Rector, B., Eds., The Kidney, 8th Edition, Saunders Elsevier, Philadelphia, 1567-1595.

[8] Millar, L.K. and Cox, S.M. (1997) Urinary Tract Infection Complicating Pregnancy. Infectious Disease Clinics of North America, 11, 13-26. https://doi.org/10.1016/S0891-5520(05)70339-1

[9] Arulkumaran, N. and Lightstone, L. (2013) Sever Pre-Eclampsia and Hypertensive Crises. Best Practice \& Research Clinical Obstetrics \& Gynaecology, 27, 877-884.

[10] Bartsch, E., Medcal, F.K.E., Park, A.L., Ray, J.G. and High Risk of Preeclampsia Identification Group (2016) Clinical Risk Factor for Preeclampsia Determined in 
Early Pregnancy: Systematic Review and Meta-Analysis of Large Cohort Studies. BMJ, 353, i1753.

[11] ACOG Committee on Practice Bulletins (2001) ACOG Practice Bulletin. Chronic Hypertension in Pregnancy. Obstetrics \& Gynecology, 98, 177-185.

[12] George, J.N. (2006) Clinical Practice. Thrombotic Thrombocytopenic Purpura. The New England Journal of Medicine, 354, 1927-1935. https://doi.org/10.1056/NEJMcp053024

[13] Berg, C.J., MacKay, A.P., Qin, C., et al. (2009) Overview of Maternal Morbidity during Hospitalization for Labor and Delivery in the United States: 1993-1997 and 2001-2005. Obstetrics \& Gynecology, 113, 1075-1081.

[14] Bellart, J., Gilabert, R., Miralles, R.M., Monasterio, J. and Cabero, L. (1998) Endothelial Cell Markers and Fibrinopeptid A to D-Dimer Ratio as Measure of Coagulation and Fibrinolysis Balance in Normal Pregnancy. Gynecologic and Obstetric Investigation, 46, 17-21. www.karger.com/Article/Abstract/9989

[15] De Vries, J.I., van Pampus, M.G., Hague, W.M., Bezemer, P.D., Joosten, J.H. and FRUIT Investigators (2012) Low-Molecular-Weight Heparin Added to Aspirin in the Prevention of Recurrent Early-Onset Pre-Eclampsia in Women with Inheritable Thrombophilia: The FRUIT-RCT. Journal of Thrombosis and Haemostasis, 10, 6472.

[16] Connaghan, D.G., Francis, C.W., Lane, D.A. and Marder, V.J. (1985) Specific Identification of Fibrin Polymers, Fibrinogen Degradation Products, and Cross Linked Fibrin Degradation Products in Plasma and Serum with a New Sensitive Technique. Blood, 65, 589-597.

[17] Sibai, B., Dekker, G. and Kupferminc, M. (2005) Pre-Eclampsia. Lancet, 365, 785799. https://doi.org/10.1016/S0140-6736(05)71003-5

[18] Pottecher, T. and Luton, D. (2009) Prise en Charge Multidisciplinaire de la Prééclampsie. French. Elsevier, Masson SAS, Issy Les Moulineaux.

[19] Carty, D.M., Delles, C. and Dominiczak, A.F. (2010) Preeclampsia and Future Maternal Health. Journal of Hypertension, 28, 1349-1355. https://doi.org/10.1097/HJH.0b013e32833a39d0

[20] Duley, L. (2009) The Global Impact of Pre-Eclampsia and Eclampsia. Seminars in Perinatology, 33, 130-137. https://doi.org/10.1053/j.semperi.2009.02.010

[21] Ali, A.A., Okud, A., Khojali, A. and Adam, I. (2012) High Incidence of Obstetric Complications in Kassala Hospital, Eastern Sudan. Journal of Obstetrics and Gynaecology, 32, 148- 149. https://doi.org/10.3109/01443615.2011.637140

[22] Pinheiro, M.B., et al. (2012) D-Dimer in Preeclampsia: Systematic Review and Meta-Analysis. Clinica Chimica Acta, 414, 166-170. https://doi.org/10.1016/j.cca.2012.08.003

[23] Bozkurt, M., Yumru, A.E., Sahin, L. and Salman, S. (2015) Troponin 1 and D-Dimer Levels in Preeclampsia and Eclampsia: Prospective Study. Clinical and Experimental Obstetrics \& Gynecology, 42, 26-31.

[24] Lee, A.J., Fowkes, G.R., lowe, G.D. and Rumley, A. (1995) Determinant of Fibrin D-Dimer in the Edinburgh Artery Study. Arteriosclerosis, Thrombosis, and Vascular Biology, 15, 1094-1097.

[25] Terao, T., Maki, M., Ikenoue, T., et al. (1991) The Relationship between Clinical Signs and Hypercoagulable State in Toxemia of Pregnancy. Gynecologic and Obstetric Investigation, 31, 74-85. https://doi.org/10.1159/000293106

[26] Schjetiein, R., Haugen, G. and Wisloff, F. (1997) Markers of Intravascular Coagulation and Fibrinolysis in Preeclampsia: Association with Intrauterine Growth Retar- 
dation. Acta Obstetricia et Gynecologica Scandinavica, 76, 541-546.

https://doi.org/10.3109/00016349709024580

[27] Bellart, J., Gilabert, R., Fontcuberta, J., Carreras, E., Miralles, R.M. and Cabero, L. (1998) Coagulation and Fibrinolysis Parameters in Normal Pregnancy and in Gestational Diabetes. American Journal of Perinatology, 15, 479-486. https://doi.org/10.1055/s-2007-994069

[28] He, S., Bremme, K. and Blomback, M. (1997) Acquired Deficiency of Ant Thrombin in Association with a Hypercoagulable State an Impaired Function of Liver and/or Kidney in Preeclampsia. Blood Coagulation \& Fibrinolysis, 8, 232-238. https://doi.org/10.1097/00001721-199706000-00004

[29] Heilmann, L., Rath, W. and pollow, K. (2007) Hemostatic Abnormalities in Patients with Severe Preeclampsia. Clinical and Applied Thrombosis/Hemostasis, 13, $285-$ 291. https://doi.org/10.1177/1076029607299986

[30] Dusse, L., Viera, L. and Caralho, M. (2003) Avaliação do dímero D (D-Di) na doença hipertensiva específica da gravidez (DHEG)-D-Dimer Plasma Levels Assessment in Preeclampsia. Jornal Brasileiro de Patologia e Medicina Laboratorial, 39, 199-202.

[31] Catarino, C., Rebelo, I., Belo, L., et al. (2008) Relationship between Maternal and Cord blood Hemostatic Disturbances in Preeclampatic. Thrombosis Research, 123, 219-224. https://doi.org/10.1016/j.thromres.2008.02.007

Submit or recommend next manuscript to OALib Journal and we will provide best service for you:

- Publication frequency: Monthly

- 9 subject areas of science, technology and medicine

- Fair and rigorous peer-review system

- Fast publication process

- Article promotion in various social networking sites (LinkedIn, Facebook, Twitter, etc.)

- Maximum dissemination of your research work

Submit Your Paper Online: Click Here to Submit

Or Contact service@oalib.com 